\title{
Localized Advantage in a Global Economy: The Case of Bangalore
}

\author{
Anil Nair - David Ahlstrom - Larry Filer
}

\begin{abstract}
Executive Summary
This article examines how and why firms in Bangalore, a city in southern India, have achieved success in the global software industry. We use Porter's "diamond framework" to analyze information obtained from secondary sources and interviews with engineers, managers, and top executives from software firms and officials involved in Bangalore's development. While we found some aspects of the case conform to Porter's framework, many other elements tend to diverge from the model. Thus, the article contributes to the Porter's diamond model literature by extending its application to assessing the development of successful regions in knowledge-based industries in developing economies. The discussion in the article would be of value to officials interested in creating such successful regions, as well as international business executives interested in the opportunities afforded by locating in these regions. (c) 2007 Wiley Periodicals, Inc.
\end{abstract}

\section{INTRODUCTION}

In addition to California's Silicon Valley, several regions have developed a distinct reputation in the information technology industry. These include "Silicon

Anil Nair is an associate professor in the management area in the College of Business and Public Administration (CBPA). He obtained his PhD with a major in management and minor in international business at the Stern School of Business, New York University. His research has examined how innovations generate industry heterogeneity, and the impact of such heterogeneity on firm behavior and performance. He has also studied strategy process and implementation issues such as learning, top management teams, structure, and governance. His international interests include study of evolution of emerging markets such as China and India, and regional clusters within them. He has taught strategic management at the undergraduate, MBA, PhD, and executive levels.

David Ahlstrom is a professor in the Department of Management at the Chinese University of Hong Kong and senior editor of the Asia Pacific Journal of Management. He has lived and work in the Asia Pacific region for over 15 years and has taught in Hong Kong for about 12 years, primarily in the areas of organizational behavior, international management, and the management of innovation. Professor Ahlstrom has published over 50 refereed journal and book articles in publications such as the Academy of Management Review, the Strategic Management Journal, Entrepreneurship Theory \& Practice, Thunderbird International Business Review, and the Asia Pacific Journal of Management. His research interests include international management, management in Greater China, and venture capital and entrepreneurship in emerging economies.

Larry Filer is an associate professor in the Department of Economics at Old Dominion University. His work includes research on international capital flows, comparisons of alternative exchange rate regimes, and international macroeconomic policy coordination. His work has appeared in the Strategic Management Journal, Journal of World Business, and Journal of Macroeconomics, among others.

Thunderbird International Business Review, Vol. 49(5) 591-618 • September-October 2007 
Dominion" in northern Virginia, "Silicon Island" in Taiwan, "Silicon Alps" in Austria, and "Silicon Saxony" in eastern Germany (Bresnahan, Gambardella, \& Saxenian, 2001; Haavind, 1999; Karnath, 1998; Matthews, 1997; Porter, 1998). The success of such regions has considerable relevance for practicing managers and public policy officials, and has attracted much attention from scholars

Several firms that develop computer software and provide information technology services have emerged in and around Bangalore, a city located in India's southern state of Karnataka. in management, (e.g., Porter, 1990, 1998; Tallman, Jenkins, Henry, \& Pinch, 2004), public policy (e.g., Saxenian, 1994), and economics (e.g., Cooke, 2001). As Zaheer and Manrakhan (2001) observe, such regional success is all the more important for managers and policymakers alike to understand in an era of globalization and increased foreign direct investment, inexpensive communication, and mobile labor markets (Reid, DeMartino, \& Zyglidopoulos, 2005).

Several firms that develop computer software and provide information technology (IT) services have emerged in and around Bangalore, a city located in India's southern state of Karnataka. Bangalorebased firms such as Infosys and Wipro have succeeded by serving their clients by a combination of offshore work in India with on-site work at client sites. An evidence of their success is that Indian software exports have grown $40-45 \%$ every year since the mid-1990s and have topped $\$ 23$ billion in 2005 (www.nasscom.com). Table 1 displays the revenues of the Indian software firms with headquarters in Bangalore, and Figure 1 displays the software exports from India.

The success of Bangalore has attracted considerable attention of the popular business press, business and world leaders (e.g., Hof \& Kripilani, 2003; Rao, 1997), and some academics (Arora, Arunachalam, Asundi, \& Fernandes, 2001; Saxenian, 2004). Bangalore's success raises several distinct, yet related questions. How did Bangalore become a center for software and IT service clustering? Why is it that Bangalore-based firms were able to become successful in the worldwide IT industry? And what are the implications for government policymakers and international business executives?

This article addresses these questions using the "diamond model" developed by Porter $(1990,1998)$ to explain the presence and sustainability of globally competitive industries within countries. We use the Porter model as a framework to develop our analysis and direct our research, as the vast number of issues that would be relevant to Bangalore's success makes its study intractable and an invitation to chaos without a framework. ${ }^{1}$ 
Table 1. Revenues of Bangalore-Headquartered Indian Software Firms (2005)

\begin{tabular}{|c|c|c|c|c|c|}
\hline No & Company Name & Area & Founding & Employees & $\begin{array}{l}\text { U.S. } \\
\$ \text { Million }^{\mathrm{a}}\end{array}$ \\
\hline 1 & Infosys & Consulting, IT services, BPO & 1981 & 32,178 & 1541.77 \\
\hline 2 & Wipro & $\begin{array}{l}\text { Hardware \& software, IT } \\
\text { services, consulting, and IS } \\
\text { outsourcing }\end{array}$ & 1981 & 42,385 & 1502.22 \\
\hline 3 & iGate & $\begin{array}{l}\text { Software solutions and } \\
\text { services }\end{array}$ & 1993 & 3,952 & 123.55 \\
\hline 4 & MphasiS BFL & Software services, BPO & 1992 & 8,375 & 106.88 \\
\hline 5 & $\begin{array}{l}\text { Infinite Computer } \\
\text { System }\end{array}$ & $\begin{array}{l}\text { Software development and } \\
\text { consultancy }\end{array}$ & 1999 & 2,500 & 130.66 \\
\hline 6 & Sonata Software & $\begin{array}{l}\text { Software services and IT } \\
\text { consulting }\end{array}$ & 1986 & 1,300 & 66.22 \\
\hline 7 & Mindtree Consulting & $\begin{array}{l}\text { Software services, application } \\
\text { and offshore development, } \\
\text { software testing, and IT } \\
\text { consulting }\end{array}$ & 1999 & 2,016 & 54.44 \\
\hline 8 & Sasken Technologies & $\begin{array}{l}\text { Telecom software and } \\
\text { solutions }\end{array}$ & 1989 & 2,200 & 53.55 \\
\hline 9 & Tally Solutions & $\begin{array}{l}\text { Financial accounting and } \\
\text { management software }\end{array}$ & 1986 & 290 & 50.88 \\
\hline 10 & Aditi Technologies & $\begin{array}{l}\text { Software design, development, } \\
\text { services, and IT consulting }\end{array}$ & 1994 & 498 & 26.88 \\
\hline
\end{tabular}

\footnotetext{
Source: Dataquest (2005), Volumes I and II.

a Converted from Indian currency @ U.S. \$1 = Indian Rupees 45.

This list excludes foreign MNEs headquartered in Bangalore, firms mainly in the hardware sector, and Indian software firms with headquarters in other cities such as Mumbai, Chennai, Hyderabad, Delhi, Noida, Gurgaon, Pune, and Calcutta.
}

\section{Figure 1. Software Exports from India}

\section{Software and Service Exports (excludes BPO)}

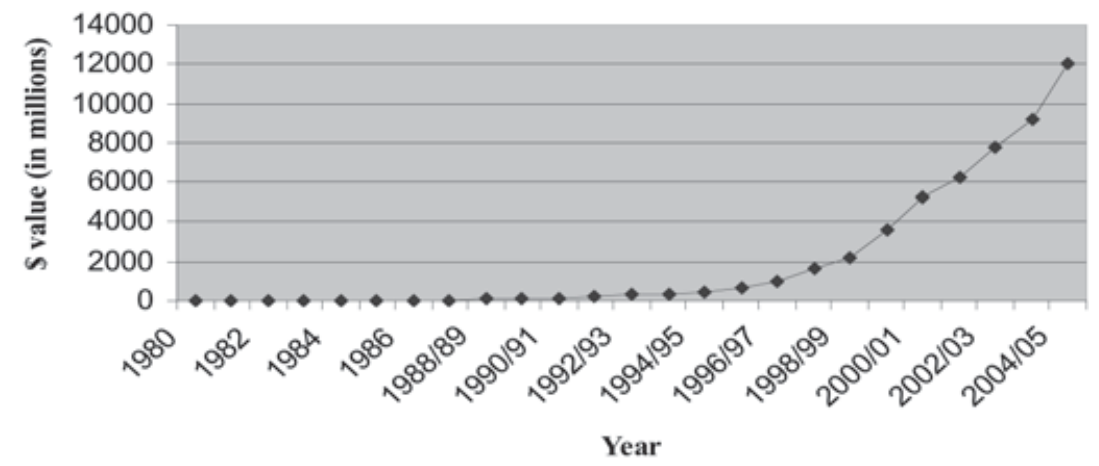

Source: NASSCOM reports.

Note. BPO: Business Process Outsourcing 
The increasing capabilities of computer hardware have led to the development of ever more complex and diverse software to exploit them.
The article is organized as follows. First, we briefly outline the structure of the software industry. Second, we review Porter's model and highlight its applicability and limitations. Next, we describe our methodology and findings. The article concludes with a discussion of the implications of the findings for Porter's model and the relevance of the findings for managers in global firms.

\section{THE SOFTWARE INDUSTRY}

Software comprises instructions that drive the operations of devices, such as computers, cell phones, automobile brakes, and global positioning systems. These instructions are written in various programming languages and may perform a range of functions. For example, in a computer, the operating system software manages the input-output operations of the device, its storage, and communication with peripherals. Application software allows users to perform specific tasks (such as edit documents), perform calculations, process employees' payroll, and so forth. The earliest adopters of computers wrote their own programs to instruct the computer to perform certain tasks. Later computer manufacturers started bundling the commonly used programs with the hardware. As the cost and complexity of developing software increased, it became unbundled from the hardware (Tannenbaum, 2001) and was increasingly performed by specialists. The increasing capabilities of computer hardware have led to the development of ever more complex and diverse software to exploit them.

The software industry is thus heterogeneous and includes firms that develop software for different needs and users, such as telecommunications, banking, insurance, and automobile manufacturers. Firms also differ in how they deliver the software; some, such as Microsoft, offer packaged software that can be bought off the shelf and installed by the user, others customize standard packages such as SAP or Oracle to user needs, and some others develop completely customized software solutions based on user needs.

\section{THE DIAMOND MODEL}

Porter's (1990) diamond model is based on a study of successful regional industries (such as the Swiss banking and pharmaceutical, U.S. commercial aircraft and motion pictures, and Japanese semiconductors and VCRs) in ten countries. The measure of global success 
was the "presence of substantial and sustained exports to a wide array of other nations and/or significant outbound foreign investment based on skills and assets created in the home country" (Porter, 1990). Porter found that an industry's competitiveness was geographically concentrated typically in a single town or region (also see, Rugman \& Verbeke, 1993)—sparkling wines from Champagne and the fax machine manufacturers in eastern Japan being two notable examples. Such geographical concentration of firms within an industry comprises a cluster (Saxenian, 1994). ${ }^{2}$ Porter's model identified the factors that, individually and as a system, contributed to each cluster's success. The four main components in the model were "factor conditions," "demand conditions," "related and supporting industries," and "firm strategy, structure, and rivalry." Porter identified two additional aspects - the role of government and chance events - that played critical roles in cluster success by impacting the four components of the diamond.

While Porter's model is now included in most standard texts in strategy and international business (e.g., Grant, 2001; Hill \& Jones, 2004; Hodgetts, Luthans \& Doh, 2005), and has been widely utilized in practice, it has been subject to substantial criticism at various levels (see Bellak \& Weiss, 1993; Cartwright, 1993; Davies \& Ellis, 2000; Dunning, 1993; Grant, 1991; Grein \& Craig, 1996; Rugman, 1991; Rugman \& Verbeke, 1993a, 1993b). ${ }^{3}$ At a conceptual level, several scholars have critiqued the fundamental assumptions and assertions of the model. Narula (1993) has argued that the model ignores evidence and developments in trade theory, while others have noted that it fails to incorporate the role of culture (Van Den Bosch \& Van Prooijen, 1992a, 1992b) and exchange rates (Daly, 1993). Davies and Ellis (2000) have commented on the lack of clarity and difficulty of measurement of the constructs, as well as the lack of specificity of the cause-effect relationships and their direction. For instance, it was argued that the "related and supporting industries" part of the diamond could also be considered part of "factor conditions." Similarly, it is difficult to precisely measure the role of supporting industries, management mind-sets, government policies, and so forth and to evaluate to what extent each variable influences the final outcome-do factor conditions play the same role as demand conditions? Furthermore, others (Grein \& Craig, 1996; O'Shaughnessy, 1996) have argued that the model was mostly based on case studies of largely manufacturing industries in developed countries, raising questions about its relevance in explaining the success of service industries in developing countries and emerging markets. ....it is difficult to precisely measure the role of

supporting

industries, management mindsets, government policies, and so forth and to evaluate to what extent each variable influences the final outcome... 
Despite these critiques, scholars have used the diamond model to study successes in a wide variety of settings. These studies have offered additional perspectives on the limitations of the model. Sledge (2005) found that the model largely explained the successes of regions within the global auto industry, though the role of one of the elements of the model-firm strategy, structure, and rivalry-

...the role of factor conditions and supporting industries need to be examined within the context of developing countries, as they may not have advanced factors and comprehensive infrastructure for industry support. was unclear. Oz (2002) applied the model to successful and unsuccessful industries in Turkey and found that multinational enterprises (MNEs) - as Dunning (1993) had argued-had played a critical role. Similarly, Bellak and Weiss (1993) found in their analyses of Austrian industries that the role of foreign MNEs may be particularly important to the emergence of globally successful regions. Espana (2004) found that the success of Brazil's aircraft manufacturing industry could be explained by the model; however, in a deviation from the model, the study found that it was demanding customers in foreign markets that were important to the industry's success. Similarly, Cartwright's (1993) studies on New Zealand, Hodgetts's (1993) study on Mexico, and Rugman's (1991) studies on Canada suggest that the role of export markets may be critical for certain countries.

The above studies point out several issues that call for further specification within the Porter model, especially in relation to developing countries. First, of particular interest is the role of local demand conditions in industry success, as it is likely that domestic markets in such countries may not be able to offer the market size and sophistication that the model articulates. Second, the role of factor conditions and supporting industries need to be examined within the context of developing countries, as they may not have advanced factors and comprehensive infrastructure for industry support. Third, the role of governments in developing countries in seeding and encouraging industry success is especially intriguing and ambiguous. Fourth, based on the Sledge (2005) study, it is clear that the role of firm strategy, structure, and rivalry in industry success requires more specification. Finally, while Porter asserts that the diamond model works as a "system," the dynamics of the system are unclear. This study seeks to clarify the above issues using the case of the software industry cluster located in Bangalore.

\section{THE STUDY}

We use the replication logic approach to analyzing case study data (Eisenhardt, 1989; Yin, 2003) to examine the factors important in 
Bangalore's success. Such a method not only helps build theory and apply it in a new area or research site, but it also may be used to modify existing theory. We obtained data for our analyses from multiple sources to identify the chronology of events and to develop detailed descriptions of how events unfolded. First, we searched all the major business databases (e.g., ABI Inform, Business Periodical Index, and Ebsco Host) using the keyword search terms "Bangalore" and "software" to obtain published information on its software industry. Next, we used government and trade publications to obtain statistical information on the cluster. The secondary data gave us information about each aspect of Bangalore's software diamond, such as output and availability of engineering institutions, infrastructure support, firm characteristics, specific government policies, and markets that Bangalore-based firms serviced. We supplemented this information with extensive, semistructured interviews with senior managers, venture capitalists, and government officials associated with the Bangalore region.

\section{The Interviews}

Interviews were used for three reasons. First, in developing countries, research subjects often prefer face-to-face interviews to mailed questionnaires (Ahlstrom, Young, Chan, \& Bruton, 2004). Second, interviews are less structured than are questionnaires, so they allow the spontaneous discussion of problems-and solutions (Lee, 1999). This approach also facilitates iteration and follow-up as called for in grounded case research (Frey \& Oishi, 1995; Yin, 2003). Finally, given that this is a new research site, the benefit of conducting in-depth interviews to develop or extend theoretical understanding of a domain is well accepted (Eisenhardt, 1989; Lee, 1999).

The subjects themselves were identified first by the authors' contacts in the United States, India, and other parts of Asia. These contacts were used to develop additional contacts across a wide spectrum of firms, locations, and agencies. ${ }^{4}$ Additional subjects were identified by contacting software firms through their Web sites. During the contact, the nature of the study was explained and the person most appropriate to the study was sought. Once we identified the person, an appointment was set up for the interview. Thus, our study included interviews with subjects in leading firms, such as Infosys, Tata Consulting Services (TCS), Wipro, Mindtree, Seibel, Motorola, and smaller ones, such as Synergy Systems; top officials in federal and state governments; and two trade associations. The respondent demographics are offered in Table 2. 


\section{Table 2. Profile of Firms and Individuals Interviewed}

\begin{tabular}{|c|c|c|c|c|}
\hline$\underline{\text { Sector }}$ & $\begin{array}{l}\text { Number } \\
\text { of } \\
\text { Interviews } \\
\end{array}$ & Interviewee Levels & Experience & Organization Status \\
\hline $\begin{array}{l}\text { Information } \\
\text { Technology }\end{array}$ & 14 & $\begin{array}{l}\text { 3: Top: CEO, } \\
\text { Managing Director, } \\
\text { Executive VP } \\
\text { 2: Upper:, Director, VP } \\
\text { 7: Midlevel: Senior } \\
\text { Manager, Divisional } \\
\text { Manager, Program } \\
\text { Director, Development } \\
\text { Manager } \\
\text { 2: Lower level: Engineer, } \\
\text { Senior Engineer }\end{array}$ & $\begin{array}{l}\text { - 2: More than } \\
25 \text { years } \\
\text { - } 7 \text { : Between } \\
15 \text { to } 25 \text { years } \\
\text { - 3: Between } \\
10 \text { to } 15 \text { years } \\
\text { - 2: Less than } \\
10 \text { years }\end{array}$ & $\begin{array}{l}\text { 6: More than } \$ 500 \\
\text { million } \\
\text { - 5: Between } \$ 50 \text { to } \\
\text { \$500 million } \\
\text { - 3: Between } \$ 1 \text { to } \$ 50 \\
\text { million }\end{array}$ \\
\hline $\begin{array}{l}\text { Bangalore- } \\
\text { Based } \\
\text { Venture } \\
\text { Capital }\end{array}$ & 6 & Venture capitalists & $\begin{array}{l}\text {-3: Between } \\
10 \text { to } 15 \text { years } \\
\text { - 3: Less than } \\
10 \text { years }\end{array}$ & $\begin{array}{l}\text { Average of U.S. } \$ 50 \\
\text { million under } \\
\text { management }\end{array}$ \\
\hline Government & 3 & $\begin{array}{l}\text { Top federal/state } \\
\text { government officials } \\
\text { responsible for IT }\end{array}$ & $\begin{array}{l}\text { - 3: More than } \\
25 \text { years }\end{array}$ & $\begin{array}{l}\text { Prime Minister's Office, } \\
\text { Karnataka State } \\
\text { Government Finance } \\
\text { and Department of IT }\end{array}$ \\
\hline Trade Groups & 3 & $\begin{array}{l}\text { Top-/upper-level officials } \\
\text { of trade groups }\end{array}$ & $\begin{array}{l}-1: \text { More than } \\
25 \text { years } \\
-1: \text { Between } \\
10 \text { to } 15 \text { years } \\
\text { 1: Less than } \\
10 \text { years }\end{array}$ & NASSCOM and FICCI \\
\hline
\end{tabular}

The interview questions were initially organized based on Porter's diamond model and tapped into each aspect of the model, such as the factor issues, demand, infrastructure, firm strategy, structure, and role of government. The questions were augmented as our interview subjects identified additional information. Toward the latter stages of the study, we had almost 30 questions in an interview protocol that reached five pages. The questions that were emphasized within the protocol depended on the individuals being interviewed. For example, respondents from government were asked more details about the government role than those from the software industry.

\section{Data Analysis and Validation}

The interviews were conducted in English. For all interviews, the results were summarized and, if needed, the subject subsequently contacted for clarification. Interviews were coded for categories 
and subcategories by one investigator and one other researcher who was not part of the study. The initial categories were coded consistent with the key categories associated with Porter's diamond model. Additional categories of data were assembled as they emerged. Reliability proved to be nearly $90 \%$ between the two coders, and there was a very high level of agreement among the interview subjects.

Factor conditions include the

Interviews were stopped when theoretical saturation was achieved (Strauss \& Corbin, 1990). Theoretical saturation is said to have been reached when a majority of the interview subjects provided similar observations or there is an absence of significant disagreement, and there is little or no new information being provided (Strauss, 1987; Strauss \& Corbin, 1990).

nation's position

in inputs into

production, such

as human

resources, physi-

cal resources,

knowledge

\section{FINDINGS}

resource, and

capital

resources.

\section{Factor Conditions}

Factor conditions include the nation's position in inputs into production, such as human resources, physical resources, knowledge resource, and capital resources. Porter made a distinction between "basic and advanced" factors and "general and specific" factors. Basic factors include natural resources, while advanced factors consist of sophisticated skills and research capabilities and offer a more enduring basis of advantage. Furthermore, such advanced factors tend to be specific to the industry. We discuss how factor conditions were relevant to Bangalore's success in the software industry.

Scientific and Engineering Institutions. Bangalore has several engineering- and science-oriented educational institutions. Executives from several software firms in Bangalore identified the role of the Indian Institute of Science-a research-oriented graduate schooland its faculty as instrumental in the development of the software capability of the region. ${ }^{5}$ In addition, a large number of privately owned engineering colleges that were set up in Bangalore in the late 1970s and 1980s also played an important role. These colleges are notable because such private engineering colleges were initially discouraged in other parts of the country and therefore attracted students from outside Karnataka who could not get admitted to their own state's colleges. In 1999, the Indian Institute of Information Technology, a research-oriented university based on a public-private partnership between the Government of Karnataka and the information technology industry (with labs sponsored by Sun, IBM, 
Microsoft, Compaq, and Novell), was also set up in Bangalore. Bangalore presently has 24 engineering colleges and four universities, and many more dispersed outside the city, but within the state of Karnataka (www.bangaloreit.com). Bangalore and the surrounding areas produce about 30,000 engineers; according to the National Association of Software and Service Companies (NASSCOM) estimates,

The presence of the public-sector engineering firms and the private engineering colleges attracted people from around the country to Bangalore and has created a diverse, multilingual, tolerant, and cosmopolitan culture. about $35 \%$ of these are in the IT-related areas. Thus, the Bangalore region has an abundant supply of technically qualified personnel. According to an executive of one of India's large software firm, this talent is critical to their success. He said, "This region produces a large number of engineers and we hire the best engineering graduates ... regardless of whether they are from civil, mechanical, or metallurgy. As long as they have the aptitude to learn, we can train them on the software technology ..." Our interview respondents consistently noted that their selection processes identified individuals who were not necessarily specialists in software or programming, but generalists who could be quickly trained and, most important, were problem solvers and independent learners (also see Schlosser, 2006).

In large part because of the presence of the science and engineering colleges, and the state's abundant natural resources, the Indian government set up several engineering and scientific public-sector enterprises in Bangalore. ${ }^{6,7}$ These public-sector enterprises attracted a large number of scientific and engineering professionals to Bangalore, thereby further adding to the availability of technical personnel in the region. As one subject observed, "The public-sector managers formed the backbone of a cosmopolitan middle class whose children also pursued careers in science and engineering, thereby adding to the pool of potential employees."

Cosmopolitan Culture, Affordability, and Agglomeration. The presence of the public-sector engineering firms and the private engineering colleges attracted people from around the country to Bangalore and has created a diverse, multilingual, tolerant, and cosmopolitan culture. Furthermore, compared to other older cities such as Mumbai, real estate costs and living and commuting expenses were lower in Bangalore. The lower costs made it attractive for entry-level engineers to locate in Bangalore and start a family. Bhaskar Pramanik, managing director of Sun Microsystems, noted that Bangalore was a great location because of its ability to attract people from anywhere in the world (Ribeiro, 2001). The respondents in our interviews consistently emphasized the importance of Bangalore's affordability, culture, and the presence of other firms in the area as the reasons for their preference for Bangalore. A senior 
manager from one of the large Indian software firms we interviewed from Mumbai said he found it difficult to attract talented software engineers to Mumbai because of its high real estate costs compared to Bangalore.

U.S. Experience. A large number of students graduating from engineering colleges joined Indian software firms such as Infosys, Wipro, and Tata Consultancy Services that sent them to serve clients abroad, especially in the United States. One of the engineers we interviewed who had been sent to the United States said that such firms were often referred to as "body shops," and the engineers were called "code coolies." However, this experience offered the engineers not only the technical skills needed by their U.S. clients, but also the managerial and social skills needed to operate in the U.S. business environment. Several respondents in our interviews noted that the U.S. experience was invaluable, as the expatriates not only worked together, but also socialized and lived together in hotels/motels while on extended assignments in the United States, thereby establishing networks that could be used later. The experience of working for clients in the United States further increased the value of the software engineers to multinational companies (MNCs) setting up operations in India, and Indian firms interested in serving U.S. markets. As the Bangalore software industry boomed, many U.S.-based Indian software personnel decided to return to India, especially after the dot-com and technology markets in the United States slowed between 2000 and 2001. The founder of a successful, fast-growing Bangalore software firm that makes operating systems for cell phones said: "Bangalore's location is particularly attractive to us because of the availability of engineering talent with global experience."

It is clear from the above discussion that while the presence of basic factors was key to Bangalore's early emergence as a center for scientific and industrial activity, Bangalore's later success in the software industry was due to the presence of advanced factors. Furthermore, it appears that, in contrast to Porter's assertion, the success of the industry appears to be driven by the availability of advanced but generalized skills that are trainable in specific areas based on industry needs.

\section{Demand Conditions}

This element of the diamond involves the nature of home demand for the industry's product or service. The characteristics of this element that drive industry success include the presence of early home demand, its rate of growth, saturation, size, and sophistication. ...it appears

that, in contrast

to Porter's asser-

tion, the success

of the industry

appears to be

driven by the

availability of

advanced but

generalized skills

that are trainable

in specific areas

based on indus-

try needs. 
U.S. Demand and Y2K. According to Dataquest, in 2004-2005, nearly $85.5 \%$ of Indian software services revenue came from exports (Dataquest, 2005). The early growth for Indian firms such as TCS, Wipro, and Infosys came about through their projects in the U.S. market. The size and number of projects surged during the 1990s as U.S. firms raced to solve the Y2K problem-a prob-

Serving the U.S. lem caused due to a coding convention in older systems that markets exposed assigned only two digits for the year count, thereby creating a Indian firms to a potential disruption as the calendar year turned 2000. U.S. firms very demanding found contracting to Indian software firms convenient because clientele and therefore forced them to develop high-quality products and services. they had lower-cost human resources proficient in the English language that were skilled in older programming languages such as Cobol and Fortran. This demand for Indian programmers led, during its peak, to almost $40 \%$ of U.S. HIB temporary work visas being granted to Indian nationals and an increase in the number of such visas (Dash, 2000). As their experience in the U.S. market increased and the $\mathrm{Y} 2 \mathrm{~K}$ challenge was overcome, India-based firms started diversifying and offering more value-added products and services.

Serving the U.S. markets exposed Indian firms to a very demanding clientele and therefore forced them to develop high-quality products and services. As several interview subjects noted, it was not home market demand but the proximity to and connections with demanding U.S. business clients that gave Indian IT firms a competitive push into international IT and back-office service markets. An executive with a large IT firm said, "We succeed in the offshoring . . . global delivery model because our frontline employees-those who are at client sites-are not only technologically competent, but they know the business context and client well." The experience of these firms later helped them to address the needs of IT markets in Germany and Japan. These clients helped the firms too. One respondent said, "Our clients have coached us and taught us a lot."

Thus, it is clear from the above findings that the Bangalore case illustrates how firms can meet tough customers outside of their home base and derive benefits otherwise consistent with the model.

\section{Related and Supporting Industries}

According to Porter, the success of an industry tends to be associated with the presence of supplier and related industries within the region. Our interview subjects agreed that the software industry's related and supporting industries would be hardware, reliable communication, and power generation industries. 
Evolution of Support Structure Ecology. While Bangalore's telecommunication standards and electric supply reliability is better than the national average, it falls short of international standards. In a city with a population of more than 6.5 million, there are less than 1 million phone lines (www.bangaloreit.com). Many of the managers interviewed suggested that the success of software firms was initially despite the lack of supporting industries. Several factors helped minimize the support structure problem. First, many software firms have installed their own generators and satellite communications equipment. Second, in recent years, firms that provide recruitment assistance, network and hardware maintenance, and marketing and accounting support have emerged to support the smaller software firms. Next, venture capital funds are also becoming available as local, Singapore-, Taiwan-, and U.S.-based venture capitalists like Vinod Khosla of Kleiner Perkins and successful Indian-American entrepreneurs offer the support infrastructure for start-ups (Grimes \& Solomon, 2005). Finally, the presence of consulting firms such as KPMG Peat Marwick, PricewaterhouseCoopers, F. Ferguson \& Co., and Ernst \& Young to assist incoming MNCs with currency and location issues has eased the entry process. Thus, a whole ecosystem of support has now evolved around the software industry.

\section{Firm Strategy, Structure, and Rivalry}

This is a fairly broad element within the diamond model and includes the conditions in the nation governing how companies are created, organized, and managed, the goals of individuals, and the nature of domestic rivalry.

Consistent with Porter's (1990, 1998) model, managerial proficiency and attitudes in Bangalore appear to have had a significant impact on the Indian software firms' global success. For instance, unlike the Indian managers and business owners in traditional industries, who were satisfied with serving a protected domestic market, the new generation of managers/owners in the software industry has a more global perspective. This perspective could be attributed to a complex set of factors. It could have been driven by the weak initial demand in the domestic market and early exposure to global markets that these firm managers experienced, and because many had been educated in U.S. or other international higher education centers. For example, its Stanford University-educated owner turned Wipro, originally a firm in the edible oils industry, into a global software firm (Ramamurti, 2001). A graduate of one of the highly ranked engineering schools, an Indian Institute of Technology (IIT), founded the second-largest software export firm, Infosys. The success of these
Consistent with Porter's (1990, 1998) model, managerial proficiency and attitudes in Bangalore appear to have had a significant impact on the Indian software firms' global success. 
Firms have gone

beyond Y2K and data-entry jobs

to application

development,

infrastructure

development,

and database

management.

firms, and the coverage they have received in the business press, has inspired a new generation of founders/managers who have not restricted themselves to the Indian market but aim to serve demanding customers in the global software market. As Khanna and Palepu (2001) observe, Infosys has even influenced the diffusion of progressive corporate governance practices among software firms in India.

\section{Strategy: From Low Cost to High Quality and Service.}

Bangalore-based firms adopted a strategy of moving up the value chain in serving their customers. Firms have gone beyond Y2K and data-entry jobs to application development, infrastructure development, and database management. According to one estimate, Wipro has 14,000 employees in research and development services alone. Respondents noted that it is no longer about costs. An executive at a midsized firm said, ". . . for our clients scalability is critical. Maintenance is where costs become crucial. Development and consulting is not so cost-sensitive." One top executive at a large firm noted, "It is like Toyota in the U.S. Earlier, customers bought Toyota because it was cheaper. But now, people buy it because of its quality and reliability. Actually, the price of Toyota may be higher than competing models now!" Another trend we noted in our interviews was the client orientation of the firms. One executive said, "We are business backward . . . we are agnostic about the technology. Unlike other firms, we do not go to clients and say here is our competency. We take the approach that we solve our clients' problems." Another executive said, "Once the client is satisfied new orders keep coming . . . for example, we had a relationship with one firm that asked us to develop their business intelligence, and as they were happy with our execution they later invited us in for a project on supply-chain optimization. Though we did not have the competency, the client asked us to develop the capabilities." Another top executive said, "We constantly ask our people: Did you go beyond your brief? The customer may want us to go from A to B, but we ask how to engage the customer from A through C. You have to be cognizant of the opportunity from B to C. For example, if the contract is for one software application, we don't just deliver the package; we ask how we can help you integrate this software with others." Hammonds (2003) calls this the Trojan Horse approach, where once a firm such as Wipro gets in through the door, it offers to perform other services for the client.

Structure: Hybrid Structure and a Learning Organization. Indian software firms that succeed in international markets were able to 
develop a unique hybrid structure that allowed them to service foreign markets with onsite personnel that would work closely with personnel in the home country. The on-site and home-site personnel were rotated so that each was aware of the others' needs. Many of our interview respondents from large software firms said that this unique feature was difficult for foreign firms (clients or competitors) to imitate as it would have led to conflict between the two groups because of the difficulty of creating consistency in the salary and benefits between the on-site and home-site employees. For example, an employee of a Bangalore-based firm with an annual salary of $\$ 20,000$ may be paid $\$ 7,000$ a month when on assignment at a client site (Hammonds, 2003). However, it may be difficult for a U.S.-based firm to persuade an employee to take a pay cut to move to Bangalore on such short assignments. An executive at a large firm said, "Managing software development projects involving a large number of people - 200 to 2,000-across different parts of the world is not easy. The model is complex; how do you slice it (the project) such that parts are managed in India and other parts in the client site." One executive noting the advantage of the Bangalore-based firms said its foreign rivals may not be able to implement the offshoring model easily. He said, "It would be difficult for our international rivals such as IBM or Accenture to be cutting jobs in the U.S. and hire people in India and take them to the U.S. For a firm such as us, this is not an issue." Thus, the structuring of the Bangalore-based firms offers them a competitive advantage over their foreign rivals.

The respondents suggested that the selection process and the personnel they hired distinguished them from clients and international rivals whose employees may often be very narrowly focused. A respondent noted, "One of the strengths of our people is they can make connections, and figure out how present problems are connected to other problems that have been solved elsewhere." Such personnel were better positioned to understand the context of their client's needs and identify consulting opportunities and propose more comprehensive solutions. One executive said, "The reason we were able to go from the Y2K stage to the Internet and Java platforms was because, when Java technology came up, we put more than 4,000 people through the training program. There is adaptability because of training and learnability." Learning is so crucial that one executive said, "We maintain a repository of processes; distilled knowledge is available about various domains. Our systems do not maintain client-specific confidential information, but generic knowledge only." The large software firms had also created intranets, knowledge portals, and discussion boards to facilitate intra-employee
The respondents suggested that the selection process and the personnel they hired distinguished them from clients and international rivals whose employees may often be very narrowly focused. 
exchange. For example, at one firm, an employee contribution to the knowledge database is evaluated, and the rating of the content also goes into the evaluation of the individual. Knowledge sharing is also achieved through informal processes such as community groups. Membership in such communities is not forced but is voluntary. The firm provides the infrastructure for the community: space for meet-

The software industry was highly fragmented, with the top ten firms' sales accounting for only $20 \%$ of the industry. ings, announcements, and informal discussion groups. Such informal groups may also exist in virtual form as discussion groups.

Competition and Growth. The software industry was highly fragmented, with the top ten firms' sales accounting for only $20 \%$ of the industry (Dataquest, 2005). In most segments of the industry, firms experience fierce competition. According to the managers we interviewed, competition for clients is not just with local firms, but also firms outside Bangalore and MNCs such as IBM, Accenture, and the like. It has resulted in pressure on firms to be cost-effective and, more important, deliver quality products and services. This competition has encouraged firms to seek international certifications from institutions such as the Carnegie Mellon University's Software Engineering Institute (CMM-SEI). For example, Bangalore-based Wipro was the first company in the world to obtain the CMM-SEI Level 5 certification one of the highest-quality rating in software development (Ramamurti, 2001). While worldwide there are only 52 companies with CMM-SEI Level 5 certification, 19 of them are in Bangalore. Some respondents noted that most Bangalore-based firms have survived because the competition has been attenuated by the high rate of growth. In 2000, when the U.S. dot-com bubble burst, the growth in the Indian market was up to 56\% (www.nasscom.com). For most firms, client satisfaction led to a larger slice of the client's outsourcing business. According to Dataquest (2005), almost $80 \%$ of growth for Indian software firms comes from existing clients. Another factor attenuating the rivalry among firms is the relatively high switching costs that clients incur when they change their service providers. An executive said, "Clients are invested in you ... it is hard to replicate this relationship." In recent years, the larger firms have been growing at a faster rate-according to Dataquest (2005), the share of top $20 \%$ companies was $50 \%$ in $2003-2004$, but by 2005 , the share had gone up to $53 \%$.

While competition in the product market space was important, a more critical competition is in the factor market space, where, according to some estimates, employee turnover rates average 33\%, and salaries have been going up by almost $20 \%$ each year (www.nasscom.com). 
It is clear from the above discussion that firm strategies, structures, and rivalry have been instrumental in the software industry's success.

\section{The Role of Government}

According to Porter, government can influence (and be influenced by) each of the four determinants. Initiatives at both the federal and state levels facilitated the growth of the software industry in Bangalore.

Economic Liberalization. The federal government in Delhi had targeted software as a growth area as early as the 1970s because of its high skill requirements, labor intensity, and foreign exchange earnings potential (Lateef, 1997). A software export scheme was launched in 1972, with an emphasis on computer and software education. Through the 1970s and into the 1980s, the software and hardware industries were largely domestic in nature and dominated by public-sector enterprises such as the Computer Maintenance Corporation (CMC). It was only in 1984 that Prime Minister Rajiv Gandhi's government started liberalizing industrial, investment, and economic policies, and the Department of Electronics (DOE) in 1984 introduced a new computer policy that liberalized import of hardware (Lateef, 1997).

It was in this context that the government accepted Texas Instruments's (TI's) proposal to establish a 100\% export-oriented subsidiary. According to one of the government officials we spoke to, with the success of Texas Instruments, the political and administrative leadership realized the economic benefits of the computer industry, and several initiatives were introduced to support it. One of these initiatives involved setting up special "Technology Parks" with allotment of land, superior infrastructure, and fiscal incentives for software exporters. Three such parks now operate in Bangalore: the Software Technology Parks (STP), International Tech Park Limited, and Electronics City. These technology parks allowed 100\% foreign equity, duty-free import, dedicated data communication links, video conferencing facilities, and custom bonding and export certification at a single point.

State-Level Initiatives. In 1997, the Government of Karnataka became the first in the country to announce an information technology policy. At the local level, the state government offers start-ups' exemptions from sales, entry, and purchase taxes on computer hardware, computer peripherals, and other capital goods and power generation sets. Firms in the IT sector were promised high-quality unin- 
terrupted electric supply power at a lower rate. If these firms installed their own power generation equipment, they received an exemption on sales tax on fuel used, and the Pollution Control Board was quick in clearing applications. In addition, the Single Window Agency (SWA) was introduced to facilitate investments. It comprised a committee that had the power to clear projects-sanctioning lands,

While the government at the national and local levels played a critical role, it must be noted that their involvement in the software industry was not as intrusive as in other industries. financing, and infrastructure facilities.

Our discussion with managers and government officials suggest that the government's role evolved with the industry. That is, while initial steps at the federal and state levels were tentative, it became more significant as the industry grew. For instance, the DOE did not initially support Indian programmers going abroad to provide on-site services to clients, which in 1989 accounted for over $90 \%$ of software revenues. It levied a $15 \%$ tax on foreign exchange expenditure on travel (Lateef, 1997). However, after the foreign exchange crisis in 1991, the government embarked on broad economic reforms and discontinued the tax on foreign travel. In 1999, the Ministry of Information Technology was set up to coordinate the initiative at government, academic, and business levels. Our interviews suggest that Bangalore's success in becoming a software hub can be attributed to the state government's active role in the early part of the industry's evolution. For instance, according to one of our respondents, though Mumbai too had a large presence in the software industry initially, the lack of the state government's active promotion of the industry resulted in its lagging behind Bangalore.

While the government at the national and local levels played a critical role, it must be noted that their involvement in the software industry was not as intrusive as in other industries. One senior government official we interviewed noted, "The bureaucrats were unable to interfere too much because the industry evolved too rapidly and they did not fully understand the industry to be able to control it." Our interviews reveal that perhaps as important as the role of the government was the role of the nongovernmental software industry trade group.

Nongovernmental Organization: Role of Trade Group .NASSCOM is a trade group of computer software and services firms that was started in 1988 and today has more than 819 members that account for $95 \%$ of the software revenues in India. NASSCOM advocates the industry's cause and acts as a catalyst for its growth by supporting IT research and education. It encourages members to adopt world-class quality standards, advises state governments on IT policy, encourages free trade policies at the national level, and strengthens the Indian IT 
brand abroad. According to our interview respondents, NASSCOM, earlier under the leadership of Dewang Mehta and now under Kiran Karnik, has very aggressively pursued the interest of the industry. For instance, as a result of its strong campaign against software privacy, in 1994 the Government of India (GOI) enacted the Copyright Amendment Bill. Further, NASSCOM has set up an antipiracy telephone hotline. Recently, as the outsourcing issue started getting politicized in the U.S. election, NASSCOM engaged in lobbying efforts in the United States to protect its members.

\section{The Role of Chance}

According to Porter, regional success may also be triggered by random events, such as acts of pure invention or major discontinuities in technology and input costs caused by events such as oil shocks, political decisions by foreign governments, and wars. Our use of the Porter model requires us to consider the role of chance factors in explaining Bangalore's success as well.

Our interviews consistently identified two events (some of which have already been described earlier) as chance events and appear to have been pivotal to Bangalore's success. First, the Y2K crisis in the United States created the surge in demand for the services of Indian software firms. Next, the collapse of the dot-com boom in the United States fueled Bangalore's growth, as U.S.-based firms searching for ways to cut costs outsourced even more activities to Bangalore.

Figure 2 displays the key elements in Porter's model in a graphical form and summarizes our findings.

\section{IMPLICATIONS}

This article examined the reasons for success of Bangalore-based firms in the global software industry. Our analysis suggests that the use of Porter's $(1990,1998)$ model is helpful in understanding Bangalore's emergence, as alternative models would not have permitted the examination of the multiple causes of Bangalore's success. However, the application of the model also suggested several concerns and limitations.

First, while Porter had argued that home market demand prepares firms for success in global markets, we found that Bangalore's software industry started off by serving not its home market, but the sophisticated North American market (cf. Davies \& Ellis, 2000). This 


\section{Figure 2. Porter's Diamond Model of Competitive Advantage}

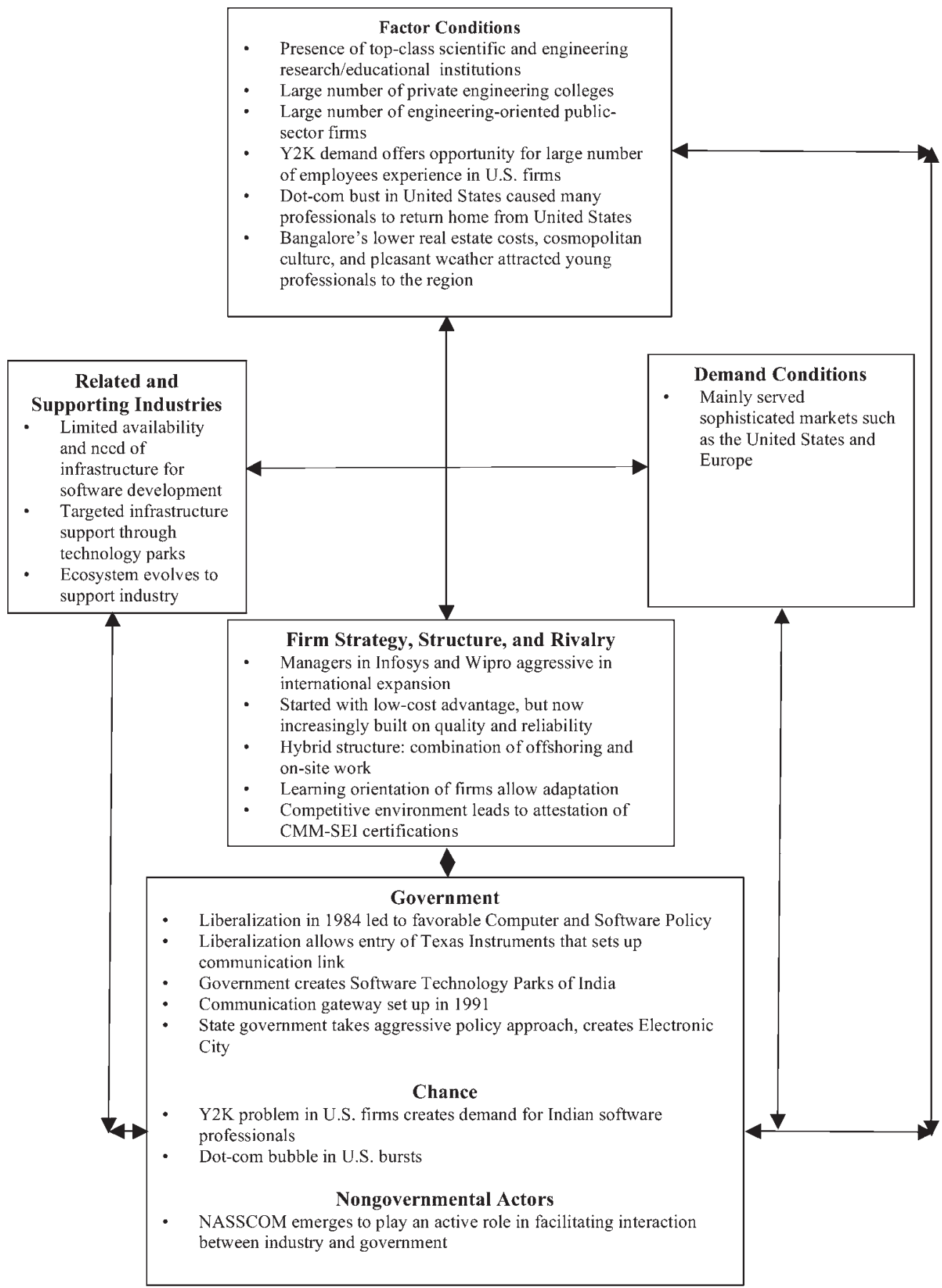


finding adds to other studies that have found that firm success within a country may be driven by demand conditions in trading partners' countries (Espana, 2004; Rugman \& D’Cruz, 1993; Rugman \& Verbeke, 1993a, 1993b).

Second, we found that the software industry in Bangalore did not have a large support structure at its inception. This is inconsistent with the Porter model and suggests that service industries perhaps need different levels of related and support structure than is required in the manufacturing sector. Many of our interview subjects noted that the support needed for software services are much less sophisticated than for manufacturing. They pointed out that the lack of success of Bangalore-based firms in manufacturing could be attributed to the poor support structure.

Third, we note that the software industry is uniquely dependent on human resources as the key factor input. As human resources are mobile, the emergence of such regions is not constrained by geographic factors. Moreover, the relative mobility of human resources compared to other factors suggests that government policies that facilitate human resources development and mobility may allow the emergence of such knowledge-based industries in any region (Zeller, 2004). Thus, Porter's notion of "domestic factor markets" may become less relevant in a knowledge-based economy, where an important factor (human resources) is mobile. On a related note, the notion that factor markets may develop due to demand conditions in another country - as happened in this instance-is supportive of the "system" aspect of Porter's model.

Fourth, we found that, similar to the global nature of the demand for the software industry, the rivals for software firms were also global. Thus, regional success could occur even if firms start off by competing with global rivals. This also offers support to Rugman's (1991) notion of the "double diamond" and Cartwright's (1993) argument that competition need not be limited to a domestic market for global success in that the critical ingredient for success may be organization learning from their environments, whether local or foreign. Finally, in a departure from Porter's model, we found that the nongovernmental software industry trade group NASSCOM played a critical role as a liaison in lobbying the government for infrastructure and serving the interests of the industry.

Based on this study, we find the following issues relevant to managers and policymakers: First, public policies that encourage investment in 
education, attract skilled professionals, and enhance their international mobility, may facilitate development of such regions. The presence of a range of engineering institutions in the region created the necessary human resource base in Bangalore for the software firms. Furthermore, as we noted earlier, the boom in the Indian software industry started as the government initiated policies that facilitated

In a rapidly evolving industry, the trade association can serve as a spokesperson that articulates the needs of the industry to the government as well as act as a line of defense for the industry against government officials. travel of software professionals to serve clients in international markets. Finally, Bangalore had the right environment in terms of cosmopolitan culture, low real estate costs, good climate, and civic amenities to attract software professionals.

Second, public policy should indicate receptiveness to business. The economic reforms that were initiated in 1984, and resumed in 1991, created an environment of support for businesses. However, it is clear from this case that policy officials should not seek to dominate or overregulate an industry. The success of software firms in Bangalore was an exception in Indian industry, and as a senior government official acknowledged, it happened primarily because the bureaucrats did not micromanage the industry. Thus, the government's role requires a delicate balancing act: facilitate industry success without dominating it. In this context, we need to highlight the critical role that can be played by industry trade associations. In a rapidly evolving industry, the trade association can serve as a spokesperson that articulates the needs of the industry to the government as well as act as a line of defense for the industry against government officials. We believe that this is especially necessary in countries where the state has dominated the economy. In such instances, individual businesses may not have enough expertise or access to influence government policy, and government officials may be too powerful. The trade association can serve to create a fairer balance of power between the two groups.

Third, the Bangalore case suggests that firms should not shy away from demanding customers and competitors in their early stages of growth. The success of firms such as Infosys and Wipro suggest that serving U.S. markets in their early stages allowed them to develop capabilities that were critical to their subsequent competitive advantage, thus supporting Ohmae's (1990) notion of competing in triad markets.

Next, the Bangalore case illustrates that to succeed in global service delivery industries, international executives may need to develop hybrid organizational forms and the capability to configure activities to exploit their presence in multiple locations. Bangalore-based firms have developed such structures that exploit the advantages of their 
home base and combine them with proximity to their clients to deliver value that is hard for rivals to replicate.

Finally, the success of Bangalore-based firms illustrates that managers need to introduce processes and systems within their organization that allow them to learn, so that they can adapt quickly to a rapidly changing environment. While the Bangalore-based firms started off at the low end of the value chain (performing coding work for the Y2K problem), they have continuously morphed to deliver more value-added service in emerging areas.

While much effort has been dedicated to analyzing agglomeration The success in software is now creating spillovers and emergence and growth of related industries such as call centers, medical transcription services, export of supplementary education services for school students, tax and accounting services, and so on. During our interviews, we found that Bangalore's growth has created pollution; intense demand on housing, roads, and water; and resentment among natives who see outsiders come in and take up lucrative IT jobs. If Bangalore's officials do not address these issues, they may find that it would slow subsequent investment, as had happened in Mumbai.

These fears have also led software firms to expand into other regions that have a high concentration of engineers and supportive state government policies. Such areas include Hyderabad in Andhra Pradesh, Pune in Maharashtra, Noida and Gurgaon near New Delhi, Chennai in Tamil Nadu, and Calcutta in West Bengal. Some of the larger software firms are also concerned that the growth in demand for Indian software professionals have led to high turnover and salaries and have sought to control costs by setting up back offices in China.

The reliance on exports has also made software industry executives in India sensitive to the risk of a backlash against outsourcing in client countries, such as the United States. During the 2004 presidential election in the United States, the NASSCOM officials lobbied congressmen and hired lobbyists Hill \& Knowlton to diffuse the tensions over outsourcing (Schroeder, 2003).

While much effort has been dedicated to analyzing agglomeration effects and competitive advantage in a developed economy setting, this study suggests that such effects may not transfer directly to emerging economies (Grant, 1991; Peng, 2000). At a theoretical level, we believe there is a need to examine in more detail the link between the different elements of the diamond model. Moreover, a limitation of this study was that other than noting the role of Texas 
Instruments, we have not discussed the role of MNEs in the growth of Bangalore's software industry - this is partly due to the limitations of the model (Dunning, 1993). Furthermore, we have applied the model to the study of a successful region, but future studies could examine regions (within India) that did not flourish in software despite the presence of enabling conditions. Several questions are raised by this study. Are there certain industries (such as software) that offer a higher probability of success in developing nations? Are such regions sustainable, especially as costs for firms in such regions inevitably rise because the demand for skills, real estate, and infrastructure exceed the supply? Can firms in such regions continue to retain their adaptability as they mature? Can increasing success cause the government to become too intrusive or less supportive? Could the export market spur a demand in the domestic market? Could such success spill over into other industries?

\section{ACKNOWLEDGMENTS}

We thank Sudhakar Rao, IAS, Finance Secretary, State of Karnataka, India, for extensive comments on this article and addressing all our questions. We also express our thanks to Professors Shaomin Li and David Selover of Old Dominion University and Marc Ahlstrom of Burlington County College for their helpful comments. Thanks are also due to Sunil Gupta, Pankaj Jain, Rahul Vadodkar, and other engineers, entrepreneurs, venture capitalists, and senior managers and executives in the software industry in Bangalore, Chennai, Mumbai, and the United States who participated in the interviews and lent their advice and insights to this study.

\section{NOTES}

1. Alternative models that could be used to study Bangalore include the classical comparative advantage model and its variants, or the models on regional success (Saxenian, 1994). However, the model by Porter essentially nests these models; key elements-comparative factor advantages, cost advantages, and labor market economies in regionalization-are captured within the Porter framework.

2. Here a cluster comprises firms that are within the same industry and develop similar products or services and thus may be involved in a competitive relationship. Please see Padmore and Gibson (1998) for a discussion on clusters. They have an expanded view of clusters that include firms with competitive or cooperative relationships, and may include suppliers to the industry.

3. Please see Appendix 1 for a summary of select studies using the Porter model published in peer-reviewed journals.

4. For example, when we interviewed Sudhakar Rao, a member of India's elite Indian Administrative Service, who served as an official in Prime Ministers Gandhi (1984-1989) and Rao's (1991-1996) administrations, he suggested we contact Karnataka state officials and NASSCOM. Individuals who played a prominent part in the interviews have been identified and thanked in the acknowledgment at the end of this article. 
5. The Indian Institutes of Science has partnered with e4e Labs to sponsor student projects and ideas into companies (Electronic Business Asia, 2001).

6. As we tried to identify factor elements driving Bangalore's success, an issue that kept appearing in our review of published materials and interviews was that Bangalore has a year-round temperate, cool climate, compared to other major Indian cities. The factor may not be relevant anymore, but it was one reason why the initial growth in engineering colleges and firms occurred.

7. The industrial policy of 1948 and 1956 established a prominent position to the public sector. This reflected a mind-set of the postindependence India's leadership that wanted to develop the country into a self-reliant economic power, the absence of private capital to launch large-scale enterprises, and the leadership's embrace of socialist principles.

\section{REFERENCES}

Ahlstrom, D., Young, M. N., Chan, E. S., \& Bruton, G. D. (2004). Facing constraints to growth? Overseas Chinese entrepreneurs and traditional business practices in East Asia. Asia Pacific Journal of Management. 21(3), 263-285.

Arora, A. Arunachalam, V. S., Asundi, J., \& Fernandes, R. (2001). The Indian software services industry. Research Policy, 30, 1267-1287.

Bellak, C. J., \& Weiss, A. (1993). A note on the Austrian “diamond.” Management International Review, 33(2), 109-118.

Bresnahan, T., Gambardella, A. \& Saxenian, A. (2001). 'Old economy' inputs for 'new economy' outcomes. Industrial and Corporate Change, 10(4), 835-860.

Cartwright, W. R. (1993). Multiple linked diamonds and the international competitiveness of export dependence industries: The New Zealand experience. Management International Review, 33, 55-69.

Clancy, P., O’Malley, E., O'Connell, L., \& Van Egeraat, C. (2001). Industry clusters in Ireland: An application of Porter's model of national competitive advantage to three sectors. European Planning Studies, 9(1): 7-28.

Cooke, P. (2001). Regional innovations, clusters, and the knowledge economy. Industrial and Corporate Change, 10, 945-974.

Daly, D. J. (1993). Porter's diamond and exchange rates. Management International Review, 33(2), 119-145.

Dash, J. (2000, May 15). H-1B visas gone; few options left. Computerworld, pp. 1-2.

Dataquest. (2005). Special issue on IT firm rankings, Volume 1 and Volume 2, July 14, Volume xxiii (13).

Davies, H., \& Ellis, P. (2000). Porter's competitive advantage of nations: Time for the final judgment? Journal of Management Studies, 37, 1189-1213.

Dunning, J. H. (1993). Internationalizing Porter's diamond. Management International Review, 33(2), 7-16.

Eisenhardt, K. M. (1989). Building theories from case study research. Academy of Management Review, 14, 532-550.

Electronic Business Asia. (2001, Feb). India. 12(2), 16.

Espana, J. (2004). Explaining Embraer's hi tech success: Porter's diamond, new trade theory, or the market at work? Journal of American Academy of Business, 4, 489-495.

Frey, J. H. \& Oishi, S. M. (1995). How to conduct interviews by telephone and in person. Thousand Oaks, CA: Sage Publications.

Grant, R. M. (1991). Porter's 'Competitive Advantage of Nations': An assessment. Strategic Management Journal, 12, 535-548.

Grant, R. M. (2001). Contemporary strategy analysis. 5th Edition. Malden, MA: Blackwell Publishing.

Grein, A. F., \& Craig, S. (1996). Economic performance over time: Does Porter's diamond hold at the national level? The International Executive, 38(3), 303-322.

Grimes, A., \& Solomon, J. (2005, October 14). Venture capitalists book a passage to India: Expatriate repatriations fuel booming investment back home; 'It's payback time for us.' Wall Street Journal, p. Cl. 
Haavind, R. C. (1999). Silicon Alps: Vacationland lures high-tech firms. Solid State Technology, 42(8): 32-33.

Hammonds, K. H. (2003, February). The new face of global competition. Fast Company, pp. 90-97.

Hill, C. W. L. \& Jones, G. R. (2004). Strategic management: An integrated approach. 6th edition. Boston, MA: Houghton Mifflin.

Hodgetts, R. M. (1993). Porter's diamond framework in a Mexican context. Management International Review, 33(2), 41-54.

Hodgetts, R. M., Luthans F. \& Doh, J. (2005). International management. 6th edition. New York, NY: McGraw-Hill/Irwin.

Hof, R. D., \& Kripilani, M. (2003, December 8). India and Silicon Valley: Now the R\&D flows both ways. Business Week, p. 74.

Karnath, L. (1998). Eastern Germany's Silicon Saxony attracting high-tech business. Solid State Technology, 41(9), 52-53.

Khanna, T., \& Palepu, K. G. (2001). Product and labor market globalization \& convergence of corporate governance: The case of Infosys and the Indian software industry. Harvard Business School Working Paper Series, No. 02-040.

Lateef, A. (1997). Linking up with the global economy: A case study of the Bangalore software industry. International Institute of Labour Studies publication.

Lee, T. W. (1998). Using qualitative methods in organizational research. Sage series on organizational research methods. Thousand Oaks, CA: Sage Publications.

Liu, X., \& Song, H. (1997). China and the multinational-A winning combination. Long Range Planning, 30(1), 74-83.

Matthews, J. (1997). A silicon valley of the East: Creating Taiwan's semiconductor industry. California Management Review, 39(4), 26-54.

Narula, R. (1993). Technology, international business and Porter's "diamond": Synthesizing a dynamic competitive development model. Management International Review, 33(2), 85-107.

Ohmae, K. (1990). The borderless world. Harvard Business Review, 68, 32-42.

O'Shaughnessy, N. J. (1996). Michael Porter's competitive advantage revisited. Management Decision, 34(6), 12-22.

$\mathrm{Oz}, \mathrm{O}$. (2002). Assessing Porter's framework for national advantage: The case of Turkey. Journal of Business Research, 55, 509-515.

Padmore, T., \& Gibson, H. (1998). Modelling systems of innovation: II. A framework for industrial cluster analysis in regions. Research Policy, 26, 625-641.

Peng, M. W. (2000). Business strategies in transition economies. Thousand Oaks, CA: Sage.

Porter, M. E. (1990). The competitive advantage of nations. New York: Free Press.

Porter, M. E. (1998). Clusters and the new economics of competition. Harvard Business Review, 76(6), 77-90.

Ramamurti, R. (2001). Wipro's chairman Azim Premji on building a world-class Indian company. Academy of Management Executive, 15(2), 13-19.

Rao, S. S. (1997, November 17). Silicon Valley goes east-Way east. Forbes, pp. 158-161.

Reid, D. M., DeMartino, R., \& Zyglidopoulos, S. C. (2005). The internationalization journey of a high-tech cluster. Thunderbird International Business Review, 47, 529-554.

Ribeiro, J. (2001, July 2). Bangalore: I.T. hot spot. InfoWorld, 23(27), 27.

Rugman, A. M. (1991). Diamond in the rough. Business Quarterly, 55(3), 61-64.

Rugman, A. M., \& D'Cruz, J. R. (1993). The "double diamond" model of international competitiveness: The Canadian experience. Management International Review, 33(2): 17-39.

Rugman, A. M., \& Verbeke, A. (1993). Foreign subsidiaries and multinational strategic management: An extension and correction of Porter's single diamond framework. Management International Review, 33(2), 71-84.

Saxenian, A. (1994). Regional advantage: Culture and competition in Silicon Valley and Route 128. Cambridge, MA: Harvard University Press.

Saxenian, A. (2004). The Bangalore boom: From brain drain to brain circulation? In K. Kenniston \& D. Kumar (Eds.), IT experience in India: Bridging the digital divide. Delhi: Sage Publications.

Schlosser, J. (2006, May 20). Infosys U. Fortune, pp. 41-43. 
Schroeder, M. (2003, Nov. 13). India aims to calm U.S. outsourcing fears; Lobbying effort counters complaints about competition for American high-tech jobs. Wall Street Journal, p. A4.

Sledge, S. (2005). Does Porter's diamond hold in the global automotive industry? Advances in Competitiveness Research, 13(1), 22-32.

Strauss, A. (1987) Qualitative analysis for social scientists. Cambridge: Cambridge University Press.

Strauss, A. \& Corbin, J. M. (1990). Basics of qualitative research. Grounded theory procedures and techniques. Thousand Oaks, CA: Sage Publications.

Tallman, S., Jenkins, M., Henry, N., \& Pinch, S. (2004). Knowledge, clusters, and competitive advantage. Academy of Management Review, 29, 258-271.

Tannenbaum, A. (2001). Modern operating systems. Englewood Cliffs, NJ: Prentice Hall.

Van Den Bosch, F. A. J., \& De Man, A.-P. (1994). Government's impact on the business environment and strategic management. Journal of General Management, 19(3), 50-59.

Van Den Bosch, F. A. J., \& Van Prooijen, A. A. (1992a). The competitive advantage of European nations: The impact of national culture-A missing element in Porter's analysis? European Management Journal, 10, 173-177.

Van Den Bosch, F. A. J., \& Van Prooijen, A. A. (1992b). European management: An emerging competitive advantage of European nations. European Management Journal, 10, 445-449.

Yang, D., Ghauri, P., \& Sonmez, M. (2005). Competitive analysis of the software industry in China. International Journal of Technology Management, 29(1,2), 64-91.

Yin, R. (2003). Case study research: design and methods. Thousand Oaks, CA: Sage.

Zaheer, S., \& Manrakhan, S. (2001). Concentration and dispersion in global industries: Remote electronic access and the location of economic activities. Journal of International Business Studies. 32, 667-686.

Zeller, C. (2004). North Atlantic innovative relations of Swiss pharmaceuticals and the proximities with regional biotech arenas. Economic Geography, 80(10), 83-111. 


\section{Appendix 1. Selected Studies on Porter's Diamond Model}

\begin{tabular}{|c|c|c|}
\hline Authors & Setting & Findings \\
\hline Sledge (2005) & $\begin{array}{l}\text { Global auto industry } \\
\text { (in eight countries) }\end{array}$ & $\begin{array}{l}\text { Generally finds support for model, except for } \\
\text { the relationship between firm strategy, structure, } \\
\text { rivalry, and national competitiveness. }\end{array}$ \\
\hline $\begin{array}{l}\text { Yang, Ghauri, and } \\
\text { Sonmez }(2005)\end{array}$ & $\begin{array}{l}\text { Software industry in } \\
\text { China }\end{array}$ & $\begin{array}{l}\text { Uses Porter model to evaluate factors facilitating } \\
\text { and impeding the developing of the industry. }\end{array}$ \\
\hline Espana (2004) & $\begin{array}{l}\text { Embraer's success in } \\
\text { Brazil }\end{array}$ & $\begin{array}{l}\text { Uses descriptive, firm-level data and finds that } \\
\text { success came through alliances, government support, } \\
\text { and demanding buyers outside the country. }\end{array}$ \\
\hline $\mathrm{Oz}(2002)$ & Turkish industries & $\begin{array}{l}\text { Using case studies, mostly finds support for model. } \\
\text { In some areas, such as domestic rivalry and role of } \\
\text { government, some of the cases contradict Porter. }\end{array}$ \\
\hline $\begin{array}{l}\text { Clancy, O'Malley, } \\
\text { O'Connell, and } \\
\text { Van Egeraat (2001) }\end{array}$ & $\begin{array}{l}\text { Industry clusters in } \\
\text { Ireland }\end{array}$ & $\begin{array}{l}\text { Examines relevance of model in industry } \\
\text { clusters and implications for industrial policy. }\end{array}$ \\
\hline Davies and Ellis (2000) & Conceptual & Offers comprehensive criticism of Porter's model. \\
\hline $\begin{array}{l}\text { Padmore and Gibson } \\
\text { (1998) }\end{array}$ & Conceptual & $\begin{array}{l}\text { Develops a new framework for regional advantage } \\
\text { using Porter's model. }\end{array}$ \\
\hline Liu and Song (1997) & China & $\begin{array}{l}\text { Uses the model to identify the role of Chinese gov- } \\
\text { ernment in developing advanced factor skills. }\end{array}$ \\
\hline Grein and Craig (1996) & Conceptual & Critical review of Porter's model. \\
\hline Van Den Bosch and & Conceptual & Offers an expanded view of the role of government. \\
\hline
\end{tabular}

De Man (1994)

Bellak and Weiss (1993) Austria

Uses Austrian case to identify shortcomings of Porter model - specifically, relevance to small countries and the role of technology and foreign investment.

\section{Rugman and Verbeke Conceptual}

(1993)

Dunning (1993)

Daly (1993)

Cartwright

(1993)

Hodgetts (1993) Mexico

Narula (1993) Conceptual

Rugman and D'Cruz Canada (1993)

Grant (1991) Conceptual
Critiques Porter's model and argues that national success may depend on international factors as well.

Discusses the role of MNEs in Porter's diamond.

Examines how exchange-rate fluctuations

impact trade flows between countries, and therefore identifies a limitation of the Porter model.

Identifies limitation of Porter model in application to export-oriented resource-intensive industries from countries with limited domestic market.

Using Mexico's example, argues that developing countries may create clusters of success by exporting to the triad countries.

Identifies the role of technology accumulation on the dynamic aspect of the cluster development.

Argues that the diamond does not explain success of firms from small trading economies such as Canada and proposes a link between such countries and diamond from a neighboring triad. Discusses the double diamond model.

Review and critique of Porter's book. Main criticism: concepts are vague, relationships among variables not clearly specified, selective data collection, and subjective interpretation. 